\title{
PERANCANGAN SISTEM INFORMASI PEMBAYARAN HUTANG PADA SUPPLIER DI PT MASTER PRINT
}

\author{
Veronika Adelia Jelita ${ }^{1}$, Hendriyati Haryani ${ }^{2}$, Tri Cahyo Nugroho ${ }^{3}$ \\ Mahasiswa Universitas Raharja ${ }^{1}$, Dosen Akuntansi Universitas Raharja ${ }^{2}$, Dosen Akuntansi \\ Universitas Raharja $^{3}$ \\ Jl. Jend. Sudirman No. 40, Modern Cikokol, Tangerang \\ Email:veronika@raharja.info ${ }^{1)}, \underline{\text { hendriyati@raharja.info }}{ }^{2)}$, tricahyo.nugroho@raharja.info $^{3)}$
}

\begin{abstract}
ABSTRAK
Penggunaan kemajuan teknologi di bidang teknologi informasi sangat strategis untuk membantu menyelesaikan masalah perusahaan, namun di PT Master Print masih belum menggunakan penerapan berbasis web, dalam pembayaran utang sehingga mengalami kesulitan dalam membedakan hutang yang sudah dan yang akan jatuh tempo. Oleh karena itu, penelitian ini bertujuan untuk mempermudah perusahaan dan staff A.P (Account Payable) yang bekerja di dalamnya untuk dapat memonitoring pembayaran hutang kepada supplier. Penelitian ini dilakukan dengan metode analisa SWOT, perancangan sistem dengan menggunakan UML (Unified Modelling Language) untuk menggambarkan secara visualisasi. Untuk bahasa pemrograman yang dipakai adalah PHP (Hypertext Preprocessor), database server dengan MySQL, sublime text 2, framework Codeigniter dan web server dengan XAMPP. Dengan sudah adanya sistem informasi pembayaran hutang ini akan memudahkan para staf divisi Purchasing dan Accounting untuk melihat dan memantau alur pembayaran utang dalam perusahaan dan juga memudahkan dalam membuat laporan hutang dagang pembelian serta juga menghasilkan laporan yang cepat dan akurat.

Kata kunci : Sistem, Informasi, Pembayaran, Utang, Hutang Dagang
\end{abstract}

\begin{abstract}
The use of technological advances in the field of information technology is very strategic to help solve company problems, but PT Master Print still does not use web-based applications in debt payments so that it has difficulty differentiating between past and maturing debts. Therefore, this study aims to make it easier for companies and A.P. (Account Payable) staff who work in it to be able to monitor debt payments to suppliers. This research was conducted with the SWOT analysis method, system design using UML (Unified Modeling Language) to describe the visualization. The programming language used is PHP (Hypertext Preprocessor), database server with MySQL, sublime text 2, Codeigniter framework and web server with XAMPP. With the existence of this debt payment information system, it will make it easier for the Purchasing and Accounting division staff to view and monitor the flow of debt payments within the company and also make it easier to create accounts payable purchase reports and also produce fast and accurate reports.
\end{abstract}

Keywords: System, Information, Payment, Debt, Accounts Payable 


\section{PENDAHULUAN}

Perkembangan dunia teknologi informasi, saat ini sangat berpengaruh dan memegang peranan penting bagi Perusahaan, instansi public yang berhubungan dengan informasi dalam pengambilan keputusan dan kelangsungan perusahaan. Pengambilan keputusan yang dimaksud merupakan salah satu hal terpenting dagang merupakan komponen yang tidak terpisahkan dari sebuah usaha, baik perusahaan berskala besar seperti perusahaan multinasional maupun berskala kecil seperti Usaha Kecil dan Menengah (UKM), hampir semua bentuk-bentuk usaha memiliki akun hutang dalam laporan keuangan mereka. Hutang memiliki kemampuan untuk meningkatkan kapasitas pendanaan sebuah perusahaan sehingga mampu untuk memenuhi kebutuhan perusahaan tersebut.

Hutang dagang merupakan kewajiban perusahaan kepada pihak lain yang harus dipenuhi dalam jangka waktu yang singkat. Kewajiban ini timbul karena pembelian bahan oleh perusahaan dagang atau karena pembelian barang dagangan oleh perusahaan yang bergerak dibidang usaha perdagangan besar/eceran secara kredit. Profitabilitas perusahaan mampu menjadi salah satu faktor yang mempengaruhi perusahaan dalam menggunakan hutang mereka. Perusahaan memiliki pengaruh terhadap penggunaan hutang, dimana kemudahan perusahaan dalam mengakses pasar modal, mendapat rating yang baik untuk penerbitan obligasi mereka, dan membayar bunga hutang yang lebih rendah. Ukuran perusahaan dikaitkan dengan reputasi sebuah perusahaan, semakin besar ukuran perusahaan maka semakin besar pula persepsi reputasi terhadap mereka. Hal ini tentu menambah kemudahan perusahaan dalam mencari hutang dalam pendanaan usahanya.

Hutang menjadi bagian dari struktur modal sebuah perusahaan memegang peranan penting dalam pembentukan risiko perusahaan. Mengenal karakteristik risiko setiap perusahaan sangat penting bagi stakeholder, yang terutama menuju pada perusahaan, investor dan juga kreditur. Hal ini sangat penting karena setiap perusahaan memiliki risiko yang berbeda-beda dan harus disesuaikan dengan selera risiko investor dan juga kreditur. informasi yang disimpan memerlukan sebuah aplikasi yang dapat menunjang segala aktivitas, mengefektifkan waktu dan mengefisiensikan biaya . Hutang mencerminkan hak tagih dari seseorang atau perusahaan lain atas sejumlah uang dan pelunasannya harus dilakukan dalam jangka pendek. Dalam melakukan transaksi hutang dagang perlu adanya informasi hutang dagang untuk setiap kreditur, informasi yang dimaksud berhubungan dengan pencatatan transaksi, proses transaksi dan laporan transaksi hutang dagang.

Penerapan sistem informasi di berbagai bidang saat ini juga banyak digunakan oleh berbagai macam badan usaha atau perusahaan. Salah satu contoh perkembangan sistem informasi yang terjadi adalah sistem informasi akuntansi online berbasis web versi 2.0. Dimana sistem ini memperlihatkan dan memberikan kemudahan untuk mengelola uang masuk juga uang keluar dari kas perusahaan.(Nur Azizah, Dedeh Supriyati, Siti Fairuz Aminah Mustapha, Holly Yang.2017:44-49).

Selain itu, masalah yang terjadi bukan hanya terhambat namun akan ada masalah lain yang timbul seperti pendapat dari Klijucnikov Aleksandr, Kozubikova Ludmila, Sopkova Gabriela (2017:45-61). Yang menyatakan bahwa masalah disiplin pembayaran akan sangat terkait dengan daya saing perusahaan. Apabila ada keterlambatan dalam pembayaran, baik pembayaran hutang ataupun pembayaran lainnya dapat menimbulkan resiko kebangkrutan dan penurunan daya saing. 


\section{METODE PENELITIAN}

Metode penelitian merupakan suatu tata cara atau kegiatan pelaksanaan penelitian rangka untuk mengumpulkan informasi atau data serta melakukan investigasi terhadap data yang telah didapatkan tersebut. yang didasari oleh asumsi-asumsi dasar, pandanganpandangan filosofis dan ideologis, pertanyaan dan isu-isu yang dihadapi. Suatu penelitian mempunyai rancangan penelitian tertentu. Rancangan ini menggambarkan prosedur atau langkah-langkah yang harus ditempuh, waktu penelitian, sumber data dan kondisi arti untuk apa data dikumpulkan dan dengan cara bagaimana data tersebut dihimpun dan diolah untuk dianalisa dalam pembuatan laporan.

\subsection{Metode Observasi (Observasi Research)}

Metode observasi dilakukan dengan cara mendatangi langsung PT Wingoh Albindo guna memperoleh data-data yang diperlukan dengan melakukan pengamatan dan melaksanakan pencatatan secara sistematis mengenai monitoring pembayaran piutang yang ada di PT Wingoh Albindo.

\subsection{Metode Wawancara (Interview Research)}

Metode wawancara yang dilakukan dengan cara tanya jawab langsung dengan stakeholder selaku penanggung jawab di PT Wingoh Albindo guna mendapatkan informasi berkaitan dengan penelitian ini dalam melengkapi hasil observasi, penulis melakukan metode wawancara atau tanya jawab untuk mendapatkan suatu data.

\subsection{Metode Studi Pustaka (Studi Literatur)}

Setelah melakukan observasi dan wawancara penulis juga mencari data dengan cara studi pustaka. Pada metode ini peneliti melakukan studi pustaka untuk melengkapi data-data yang lebih akurat dengan cara mengumpulkan data teoritis yang bersumber dari hasil kuliah, jurnal literature dari koleksi buku perpustakaan, serta sumber-sumber lain yang berkaitan dengan penyusunan skripsi tersebut. Sehingga peneliti mendapatkan gambaran secara teoritis yang berguna untuk membantu penganalisaan dan perancangan maupun penulisan penelitian ini.

\subsection{Metode Analisis Data}

Setelah metode analisa dilaksanakan untuk melengkapi laporan skripsi ini peneliti merancang sistem dengan analisis SWOT yang artinya metode perencanaan strategis yang digunakan untuk mengevaluasi kekuatan.

\section{PEMBAHASAN}

Untuk dapat menggambarkan prosedur secara keseluruhan diperlukan beberapa tahapan analisa sebagai bentuk pengumpulan informasi guna mendapatkan model yang sesuai dengan kebutuhan dan mampu memberikan solusi dengan cepat secara efektif dan efisien, mulai dari tahapan pengumpulan informasi dan kebutuhan, analisis dokumen, rancangan hubungan antar dokumen sampai dengan merancang model diagram database dan model perancangan sistem. Beberapa tahapan yang dimaksud sampai dengan model rancangan yang diciptakan dapat dilihat pada gambar 1,2,3,4,4. 


\subsection{Use Case Diagram Prosedur Berjalan}

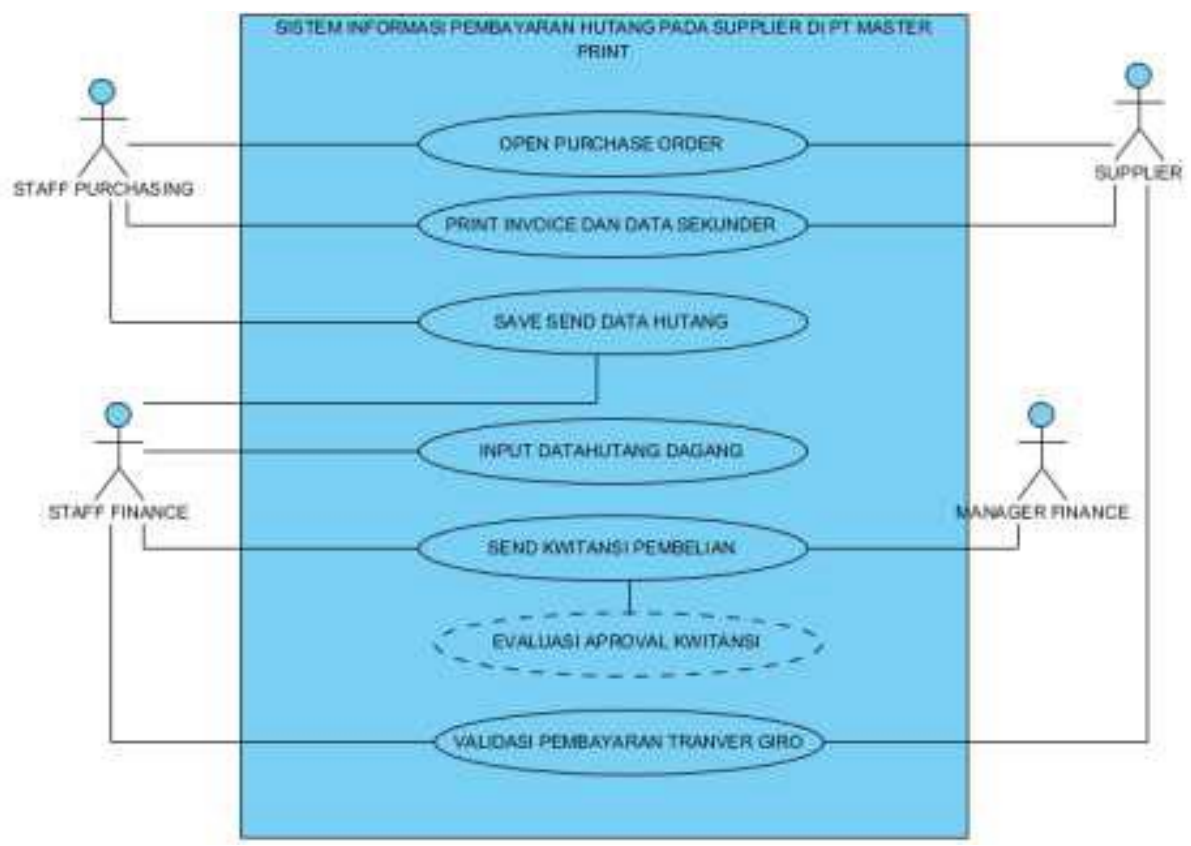

Gambar 1. Use Case Diagram

Berdasarkan gambar use case Diagram (gambar 1) yang berjalan saat ini sistem mencakup seluruh sistem yang mencakup seluruh proses pembayaran hutang yang saat ini berjalan pada PT. Master Print. Tiga aktor yang melakukan proses pembayaran hutang diantaranya: Staff Purchasing, Staff Finance, dan Manager Finance. Enam use case yang dilakukan oleh aktor.

\subsection{Activity Diagram Prosedur Berjalan}

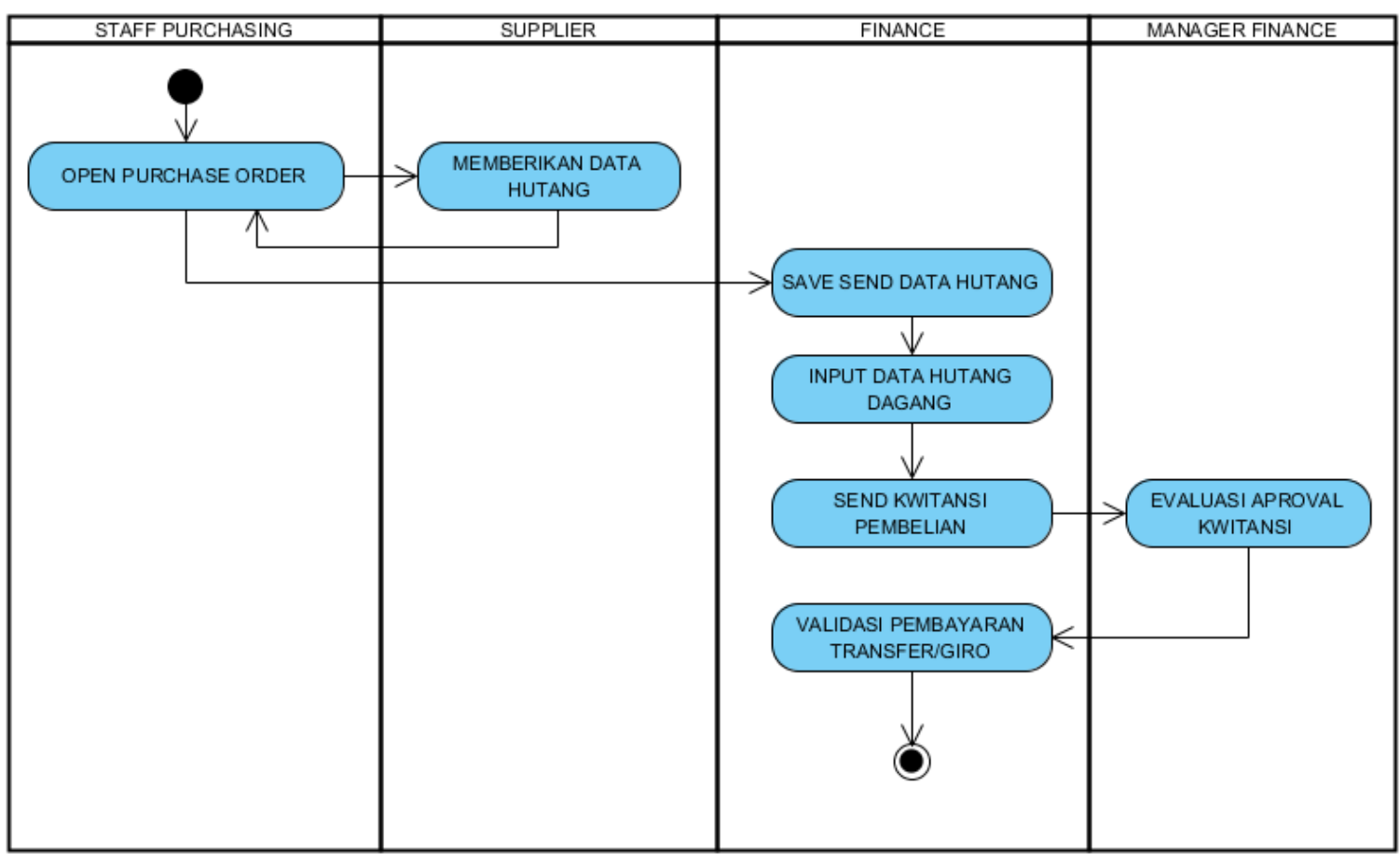


Berdasarkan gambar 3.3 Activity Diagram Pembayaran Hutang Berjalan pada saat ini terdapat: Empat Vertical Swimlane yang mencakup seluruh pembayaran hutang pada supplier yang berjalan pada PT. Master Print yang dilakukan oleh: Staff Purchasing, Staff Finance, Supplier dan Manager Finance. Satu Initial Node, awal dalam melakukan kegiatan. Tujuh Action State dari sistem yang mencerminkan eksekusi dari suatu aksi diantaranya : membuka PO, menerima invoice, memberikan invoice, melakukan rekap hutang, memberikan kwitansi pembayaran, memeriksa kwitansi hutang dan melakukan pembayaran hutang. Satu Activity Final Node, akhiran untuk mengakhiri kegiatan.

\subsection{Sequence Diagram Prosedur Berjalan}

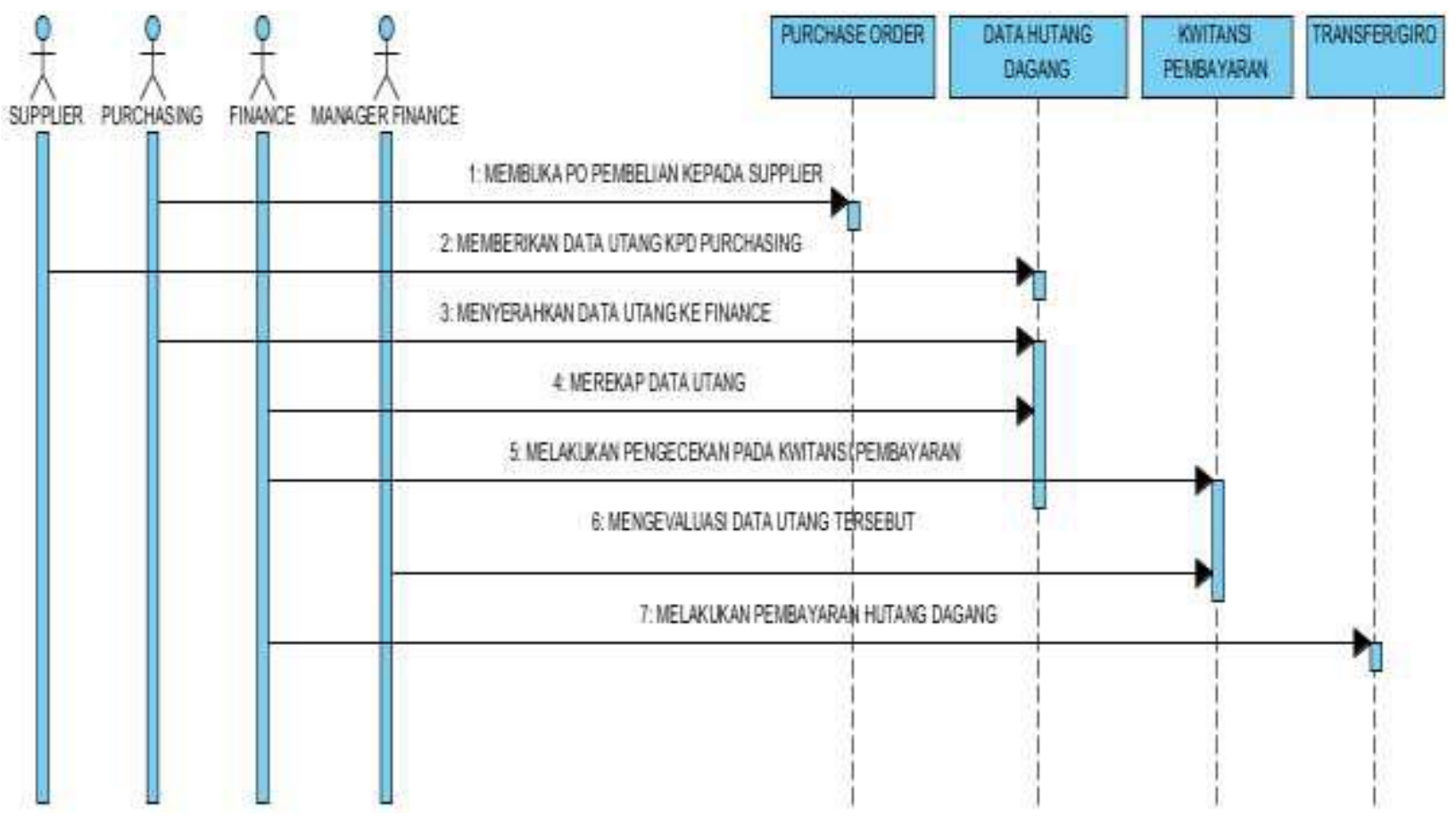

Gambar 3. Sequence Diagram

Berdasarkan Gambar 3.4 Sequence Diagram Pembayaran Hutang pada Supplier Berjalan pada saat ini terdapat : Empat aktor yang melakukan proses pembayaran hutang diantaranya : Supplier, Staff Purchasing, Staff Finance, Manager Finance. Empat lifeline antarmuka yaitu: Purchase Order, Data hutang dagang, kwitansi pembayaran, transfer/giro. Tujuh message spesifikasi dari komunikasi antar objek yang menurut informasi - informasi yang dilakukan oleh actor tersebut diantaranya: membuka PO, memberikan invoice, menyerahkan invoice, melakukan rekap hutang, memberikan kwitansi pembayaran, memeriksa kwitansi hutang dan melakukan pembayaran hutang. 


\subsection{Use Case Diagram Usulan}

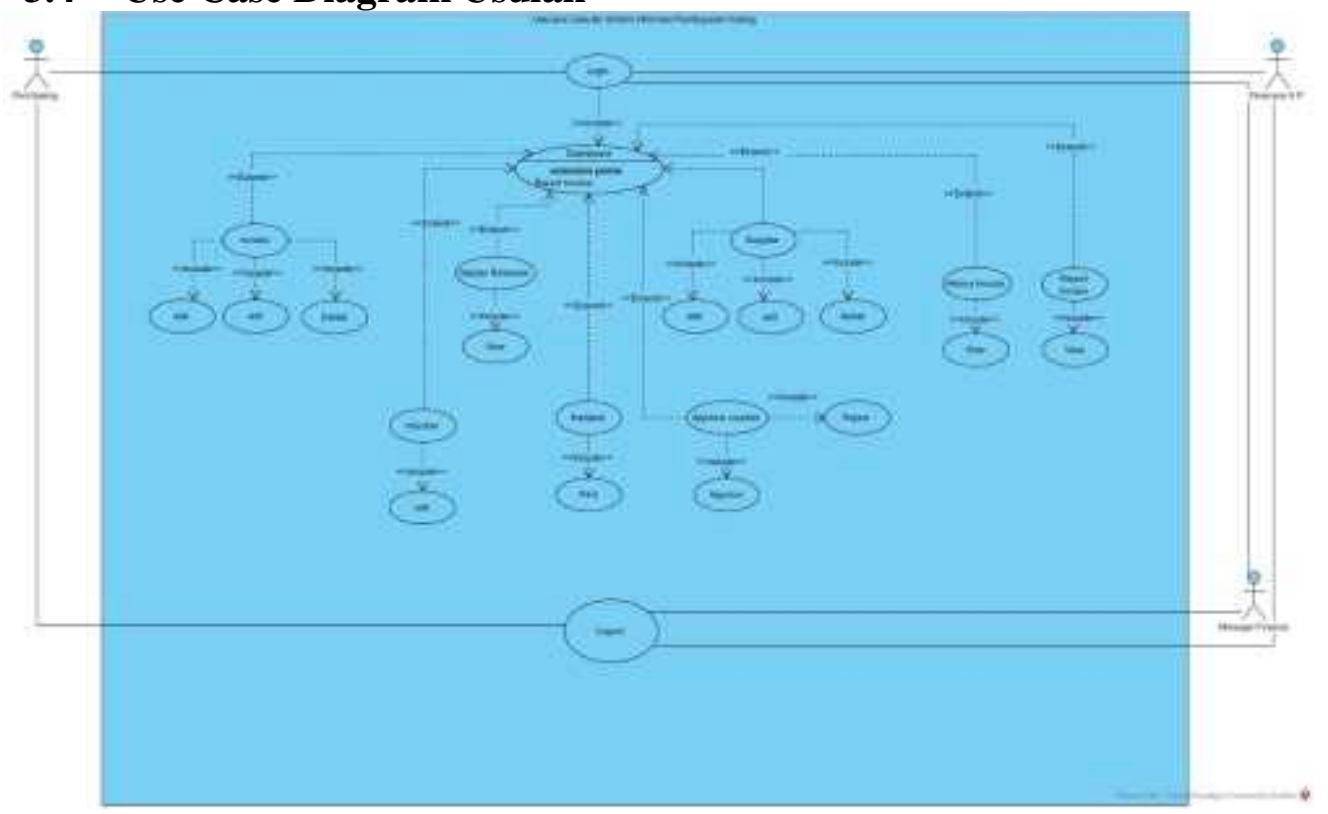

Gambar 4. Use Case Diagram

Berdasarkan gambar diatas, use case diagram Sistem Pembayaran Hutang yang diusulkan terdapat satu sistem yang mencakup seluruh kegiatan dalam proses pembayaran hutang. Tiga aktor yang melakukan kegiatan yaitu: Staff Purchasing, Staff Finance (A.P) dan Manager Finance. Terdapat Dua puluh tiga use case berupa include dan extend yang akan dilakukan oleh actor tersebut.

\section{IMPLEMENTASI}

\subsection{Rancangan Basis Data}

Untuk dapat menggambarkan bentuk basis data secara utuh, peneliti menggunakan aplikasi PHP, Database Server MySQL, sublime text 2, framework codeigniter dan web server dengan XAMPP. sebagai bentuk gambaran dasar, dan pada akhirnya bentuk rancangan basis data ini dapat disesuaikan menggunakan apa saja sesuai kebutuhan. 
ISSN: 2723-5262

Online ISSN: 2723-5270

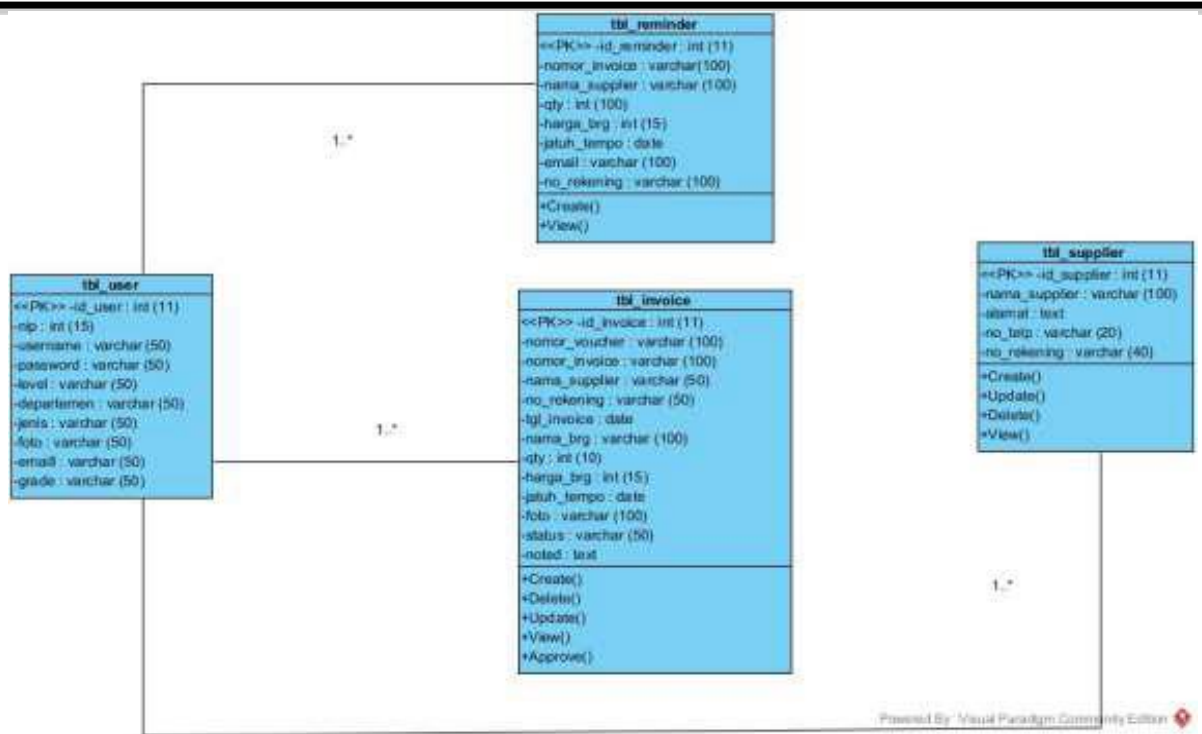

Gambar 5 Class Diagram yang diusulkan

\subsection{Rancangan Tampilan}

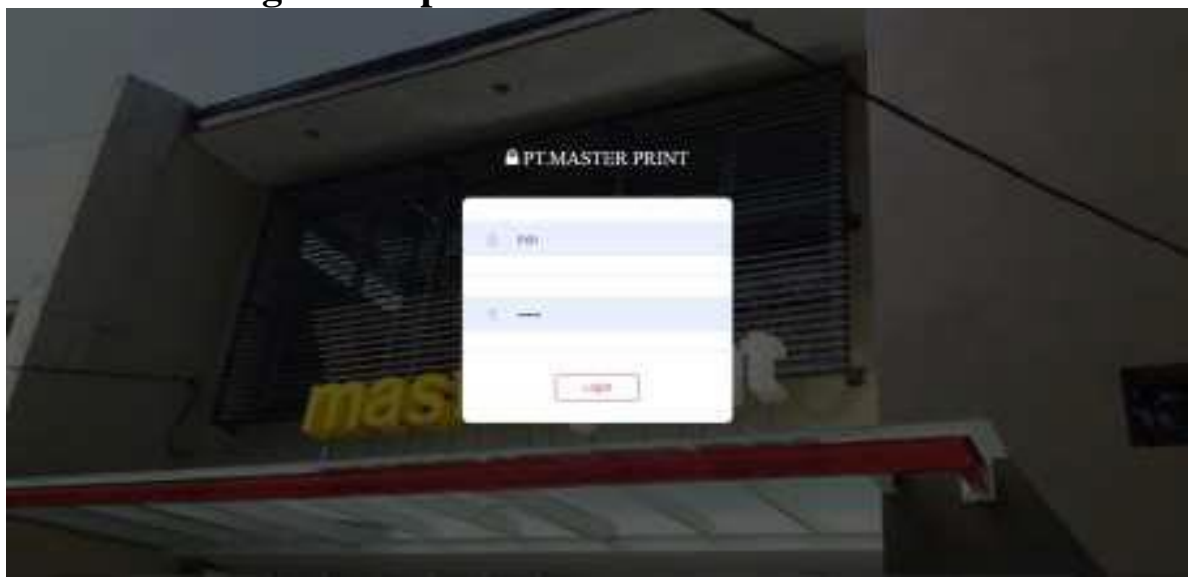

Gambar 6. Tampilan Login

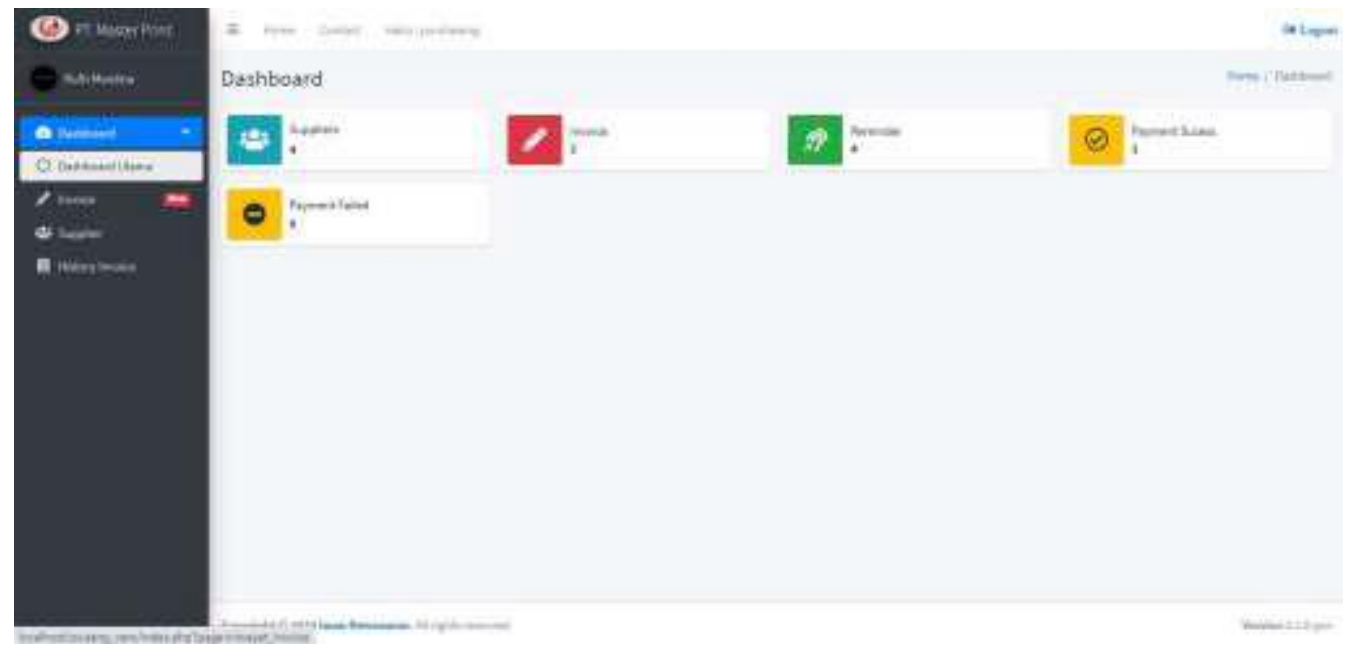

Gambar 7 Tampilan Menu Halaman Utama 
ISSN: 2723-5262

Online ISSN: 2723-5270

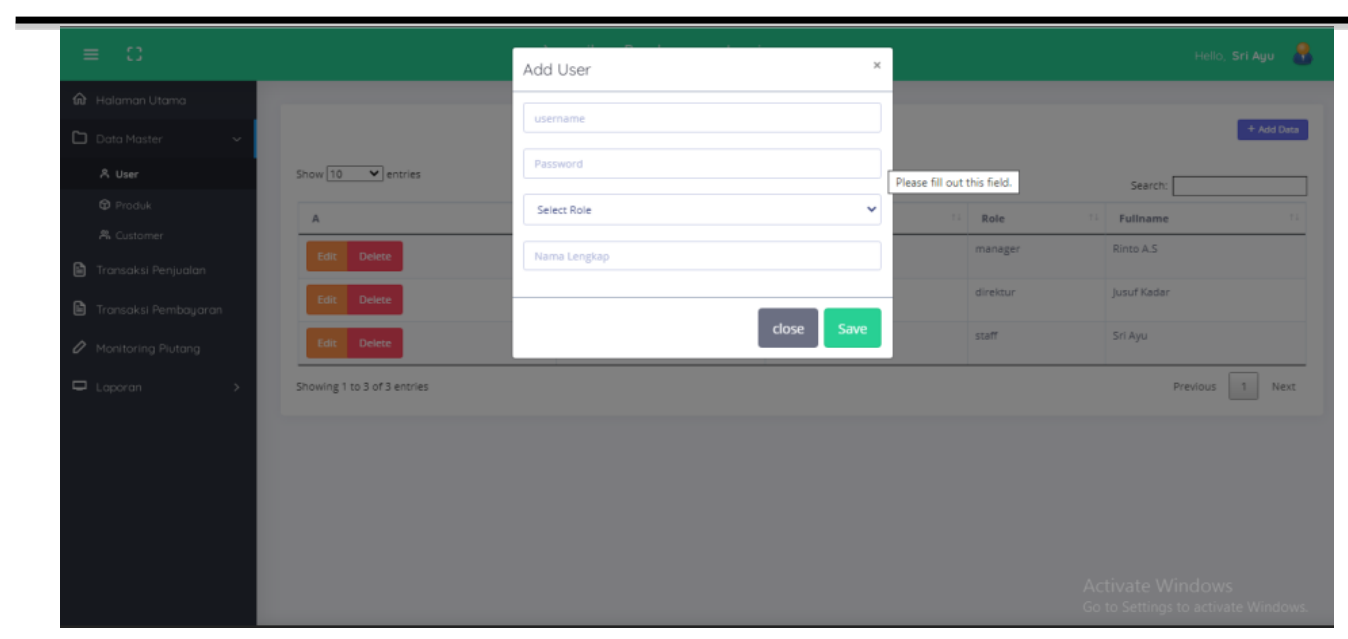

Gambar 7 Tampilan Menu Input Data Invoice Supplier

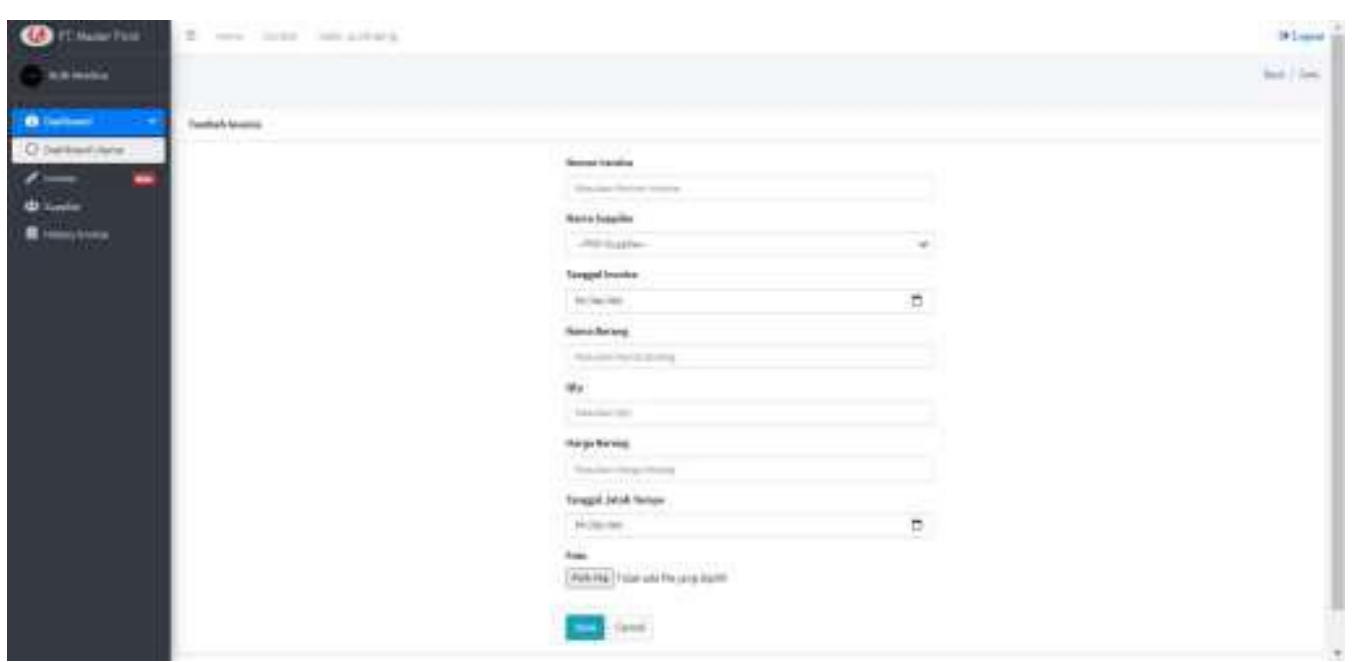

Gambar 8 Tampilan Menu Input Data Invoice Supplier

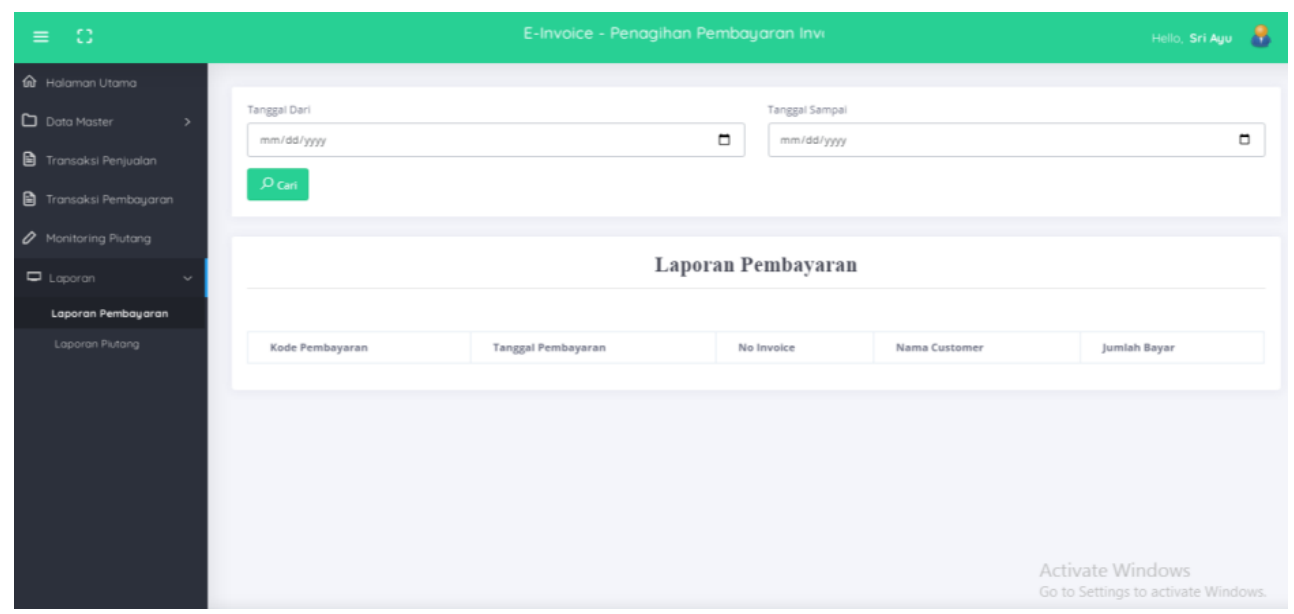

Gambar 9 Tampilan Menu Laporan Pembayaran 


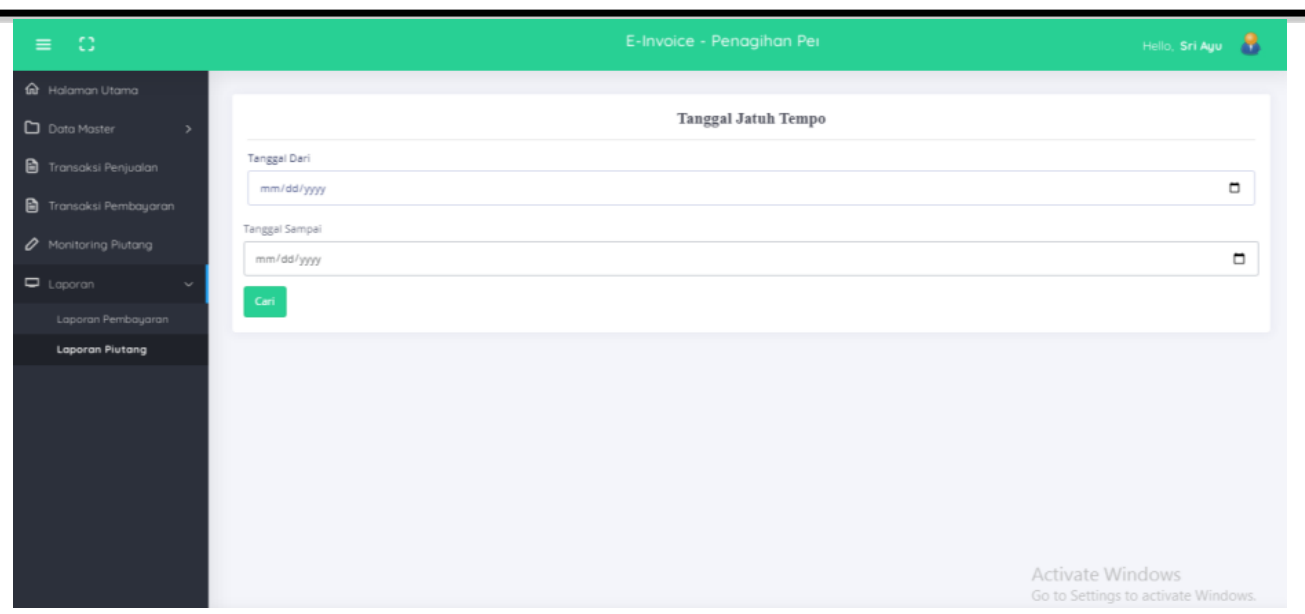

Gambar 10 Tampilan Menu Tanggal Jatuh Tempo

\section{KESIMPULAN}

Berdasarkan dari hasil penelitian yang dilakukan pada PT Wingoh Albindo, tentang monitoring pembayaran piutang dapat disimpulkan bahwa proses monitoring pembayaran piutang pada PT Wingoh Albindo yang sedang berjalan saat ini masih semi komputerisasi yaitu dengan microsoft excel. Sehingga proses untuk transaksi penjualan, pembayaran piutang, laporan penjualan dan laporan piutang juga, masih menggunakan microsoft excel sehingga membutuhkan waktu yang lama untuk menyelesaikan dan mengelola rekap pembayaran piutang karena masih manual dan tidak terlepas dari kesalahan dalam proses pengolahannya. Dimana untuk prosesnya staff marketing menerima PO dari customer, setelah itu staff gudang membuat surat jalan, staff A.R membuat invoice, setelah barang dikirim, customer melakukan pembayaran, staff A.R merekap laporan piutang yang akan diberikan ke Manager. Permasalahan yang sering terjadi pada proses monitoring pembayaran piutang saat ini yaitu dimana keluhan staff A.R untuk dapat membedakan piutang customer yang akan jatuh tempo dan yang sudah terlambat untuk membayar. Untuk merancang aplikasi ini menggunakan bahasa pemrograman PHP, Database Server MySQL, sublime text 2, framework codeigniter dan web server dengan XAMPP. Dimana prosesnya Staff A.R dapat melakukan login, menambah user, produk, data customer, transaksi penjualan, pembayaran, monitoring, laporan dan logout. Sedangkan Manajer bisa melakukan login, menampilkan dashboard, transaksi penjualan, pembayaran, laporan dan logout. 


\section{DAFTAR PUSTAKA}

[1] Abdulloh, Rohi. 2016. "Easy \& Simple Web Programming”. Jakarta: PT. Elex Media Komputindo.

[2] Agusvianto, Hendra. 2017. "Sistem Informasi Inventory Gudang Untuk Mengontrol Persediaan Barang Pada Gudang". Studi Kasus: PT. Alaisys Sidoarjo. Journal Information Engineering and Educational Technology (JIEET). 01(01). ISSN: 2549869X.

[3] Ahsyar, Khairil., Tengku. Abd Rahman. 2018: 142-149. "Sistem Monitoring Piutang Dan Inventori Barang Di PT. ANugrah Citra Pestindo". Jurnal Ilmiah Rekayasa dan Manajemen Sistem Informasi, Vol. 4 No. 2. UIN SUSKA Riau. Agustus 2018. E-ISSN 2502-8995, p-ISSN 2460-8181.

[4] Amrullah, Agit., Rifda Faticha Alfa., Danang Sutedjo., Renna Yanwastika Ariyana., Hendi S dan Eri Sasmita Susanto. 2016. "Kajian Kebutuhan Perangkat Lunak Sistem Informasi Penilaian Prestasi Kerja Pegawai Pada Fakultas Adab dan ilmu Budaya Universitas Islam negeri Sunan Kalijaga Yogyakarta”. Yogyakarta: Seminar Nasional Teknologi Informasi dan Multimedia. ISSN: 2302-3805.

[5] Amrullah, Agit., Rifda Faticha Alfa., Danang Sutedjo., Renna Yanwastika Ariyana., Hendi S dan Eri Sasmita Susanto. 2016. "Kajian Kebutuhan Perangkat Lunak Sistem Informasi Penilaian Prestasi Kerja Pegawai Pada Fakultas Adab dan Ilmu Budaya Universitas Islam Negeri Sunan Kalijaga Yogyakarta”. Yogyakarta: Seminar Nasional Teknologi Informasi dan Multimedia. ISSN : 2302-3805.

[6] Andika Jaya, Kriyan., Novi Safriadi., Anggi Perwitasari. 2018 : 22-27. "Aplikasi Monitoring dan Evaluasi Kinerja Aparatur di Kejaksaan Negeri

[7] 122

[8] Mempawah". Jurnal Sistem Informasi dan Teknologi Informasi. Kalimantan : Universitas Tanjungpura. Vol.6, No.1, Januari 2018. ISSN : 2460-3562.

[9] Anhar. 2016. "Kumpulan Source Code Visual Basic 6.0 untuk Skripsi”. PT Elex Media Komputindo: Jakarta.

[10] Aris., Indah Puspita Sari., Desi Artriyani., Tia Cahya Restiqi. 2016. "DESAIN APLIKASI SISTEM INFORMASI PENJUALAN SECARA ONLINE PADA PT. ULTINET INDONESIA”. Tangerang: STMIK Raharja ISSN: 2302-3805.

[11] Astuti, Kondar Siahaan Dui dan Joni Devitra. 2017. "Analisis dan Perancangan Sistem Informasi Simpan Pinjam pada Koperasi Pegawai Negeri Iain Sultan Thaha Saifuddin Jambi”. Jambi: Jurnal Manajemen Sistem Informasi STIKOM Dinamika Bangsa Jambi. Vol.2 No.2:516.

[12] Azizah, Nur, Lina Yuliana dan Elsa Juliana. 2017. "Rancang Bangun Sistem Informasi Penggajian Karyawan Harian Lepas pada PT. Flex Indonesia. Jurnal SENSI. Tangerang”. Perguruan Tinggi Raharja. ISSN: 2461-1409. Vol.3 No.1-Februari 2017.Maniah dan Dini Hamidin. 2017 : 2. "Analisis Dan Perancangan Sistem Informasi". Yogyakarta: Deepublish.

[13] Azizah, Nur., Dedeh Supriyati., SIto Fairuz Aminah Mustapha., Holly Yang. "The Role of Web Based Accounting Online System 2.0 as the Company's Income and Expense Management". Aptisi Transactions on Agriculture, Vol 1 No 1. Neliti. ISSN: $2622-$ 6812. Page 44-49. 